\title{
Duodenum and Ampulla of Vater Neuroendocrine Tumor Pathologic Regional Lymph Nodes TNM Finding v8
}

National Cancer Institute

\section{Source}

National Cancer Institute. Duodenum and Ampulla of Vater Neuroendocrine Tumor

Pathologic Regional Lymph Nodes TNM Finding v8. NCI Thesaurus. Code C135071.

A pathologic finding about one or more characteristics of a duodenum and ampulla of Vater neuroendocrine tumor, following the rules of the TNM AJCC V8 classification system as they pertain to staging of regional lymph nodes. 